\title{
The correlation of CD19 + CD24 + CD38 + B cells and other clinicopathological variables with the proportion of circulating Tregs in breast cancer patients
}

\author{
Mohammad Kazzem Gheybi ${ }^{1}$ Shokrollah Farrokhi ${ }^{2} \cdot$ Mohammad Reza Ravanbod $^{3}$.

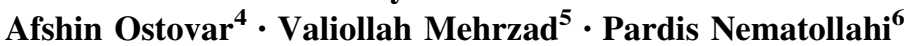

Received: 12 August 2016/ Accepted: 17 April 2017

(C) The Japanese Breast Cancer Society 2017

\begin{abstract}
Background $\mathrm{T}$ regulatory cells (Tregs) are known to negatively control immune response. The frequency of these cells was inversely correlated with clinical outcomes of breast cancer. $\mathrm{CD} 19^{+} \mathrm{CD} 24^{\mathrm{hi}} \mathrm{CD} 38^{\mathrm{hi}}$ cells also play a critical role in inflammation and autoimmune disease. However, their function in tumor immune response is less studied. In this study we aimed to determine the role of $\mathrm{CD} 19^{+} \mathrm{CD} 24{ }^{\mathrm{hi}} \mathrm{CD} 38^{\mathrm{hi}}$ cells and some other clinicopathological variables in increasing the proportion of Tregs in breast cancer patients.

Methods We selected 47 patients with invasive ductal breast carcinoma and 50 healthy controls and obtained their blood samples.

Results The proportion of circulating $\mathrm{CD} 4{ }^{+} \mathrm{CD} 25^{+} \mathrm{Foxp}^{+}$ Tregs and $\mathrm{CD} 19^{+} \mathrm{CD} 24^{\mathrm{hi}} \mathrm{CD} 38^{\text {hi }}$ cells was significantly increased in breast cancer patients. We also found that
\end{abstract}

Mohammad Kazzem Gheybi

kazzem7@yahoo.com

1 Persian Gulf Tropical Medicine Research Center, Bushehr University of Medical Sciences, Bushehr, Iran

2 Department of Immunology, Persian Gulf Tropical Medicine Research Center, Bushehr University of Medical Sciences, Bushehr, Iran

3 Department of Hematology and Oncology, Bushehr University of Medical Sciences, Bushehr, Iran

4 Department of Epidemiology, Persian Gulf Tropical Medicine Research Center, Bushehr University of Medical Sciences, Bushehr, Iran

5 Department of Hematology and Oncology, Isfahan University of Medical Sciences, Isfahan, Iran

6 Department of Cancer Pathology, Isfahan University of Medical Sciences, Isfahan, Iran increased proportion of Tregs in breast cancer is correlated with HER2 amplification, advanced clinical stages, serum TGF- $\beta 1$ and increased $\mathrm{CD} 19^{+} \mathrm{CD} 24^{\mathrm{hi}} \mathrm{CD} 38^{\text {hi }}$ cells in the peripheral blood.

Conclusion Altogether, our data suggest that as much as Tregs, $\mathrm{CD} 19^{+} \mathrm{CD} 24^{\mathrm{hi}} \mathrm{CD} 38^{\text {hi }} \mathrm{B}$ cells could also have a part in the suppression of immune response in breast cancer.

Keywords Breast cancer $\cdot T$ regulatory cells . $\mathrm{CD} 19+\mathrm{CD} 24+\mathrm{CD} 38+\mathrm{B}$ cells $\cdot$ Clinicopathological variables

\section{Introduction}

Breast cancer, a heterogeneous and complex disease, is currently the world's most frequently diagnosed cancer among women [1]. Although the incidence of breast cancer has increased constantly in developed countries over the past few decades, the mortality caused by breast cancer has decreased in recent years, partly because of improved diagnostic and therapeutic techniques and also better understanding of the pathogenesis of the disease [2]. The prognosis of the disease is strongly associated with tumor stage [3] and could also be predicted by biological characteristics of tumor cells, including expression of hormone receptors (HR) and human epidermal growth factor receptor 2 (HER2) [4]. However, it is increasingly realized that tumor cell's surrounding microenvironment also plays an important role in the disease progression [5].

Regulatory $\mathrm{T}$ cells (Tregs) are a particular subset of $\mathrm{CD} 4{ }^{+} \mathrm{T}$ cells with expression of $\mathrm{CD} 4{ }^{+} \mathrm{CD} 25^{+} \mathrm{FoxP}^{+}$and comprise about $5 \%$ of $\mathrm{CD}^{+} \mathrm{T}$ cells in the peripheral blood $[6,7]$. Tregs induce immune tolerance and they were shown to inhibit immune cells to secrete inflammatory 
cytokines and suppress autoimmunity in many autoimmune diseases [8]. In addition, their ability to mediate suppression of cancer's immune response is increasingly recognized $[9,10]$ and studies have found that Tregs play important roles in tumor scape [11]. Elevated proportion of Tregs is present within tumors, lymph nodes and peripheral blood of various types of solid and hematologic cancers including breast cancer $[12,13]$. Besides, frequency of $\mathrm{CD} 4{ }^{+} \mathrm{CD} 25^{+} \mathrm{FoxP}^{+}$cells have been demonstrated to be inversely correlated with the clinical outcomes of breast cancer [13].

Transforming growth factor- $\beta 1$ (TGF- $\beta 1$ ) plays a crucial role in suppressing immune cells. It takes part in inducing the differentiation of Tregs [14]. TGF- $\beta 1$ is secreted by many cells and it is also known as the main cytokine produced by Tregs. Studies have revealed that TGF- $\beta 1$ implicates in tumor progression including breast cancer $[13,15]$.

The pivotal role of regulatory $\mathrm{T}$ cells in suppressing antitumor immune response has been extensively studied and is almost accepted. In addition to Tregs, there is also a subset of B cells described with regulatory capacity, confirmed as regulatory B cells $[16,17]$. The identification of Bregs in human is controversial. Studies have reported regulatory functions for different $B$ cell subsets. Blair and colleagues have described Bregs with $\mathrm{CD} 19^{+} \mathrm{CD} 24^{\text {hi- }}$ $\mathrm{CD} 38^{\mathrm{hi}}$ phenotype that suppress the differentiation of $\mathrm{T}$ cells via secretion of IL-10 [18]. This suppressive effect could be mediated through induction of FoxP3 expression in $\mathrm{CD}^{+}{ }^{+} \mathrm{CD} 25^{+} \mathrm{T}$ cells $[18,19]$. Further evidences suggested that these Bregs play an essential role in pathogenesis of autoimmune diseases [16]. Although Bregs have been extensively studied in these diseases, there is a little known about their role in human cancer. Some studies have suggested their role in lymphomas and skin carcinomas $[20,21]$. A recent study also described the role of $\mathrm{CD} 19^{+} \mathrm{CD} 24^{\mathrm{hi}} \mathrm{CD} 38^{\mathrm{hi}}$ cells in suppressing tumor immunity in gastric cancer [22].

In this study, we aimed to compare breast cancer patient's $\mathrm{T}$ and $\mathrm{B}$ regulatory cells of peripheral blood with healthy individuals and assess the association between different clinicopathological variables including $\mathrm{CD} 19^{+} \mathrm{CD} 24{ }^{\mathrm{hi}} \mathrm{CD} 38^{\mathrm{hi}} \mathrm{B}$ regulatory cells with the proportion of $\mathrm{T}$ regulatory cells in the peripheral blood as a poor prognostic marker in breast cancer. To our knowledge, this is the first study that investigates the frequency of $\mathrm{CD} 19^{+} \mathrm{CD} 24^{\mathrm{hi}} \mathrm{CD} 38^{\mathrm{hi}} \mathrm{B}$ regulatory cells in breast cancer.

\section{Materials and methods}

\section{Patients and controls}

In this cross-sectional study, 47 patients diagnosed with invasive ductal breast carcinoma were enrolled between December 2014 and December 2016. Fifty age- and BMImatched females were recruited as healthy controls. Peripheral blood samples were obtained from breast cancer patients before receiving any chemotherapy or immunotherapy medications. HER2 status was determined by the latest version of ASCO/CAP HER2 testing guideline update [4]. Nottingham criteria were used to describe histological grade [23, 24]. Also the tumor size was determined by the TNM staging according to the new staging system of the American Joint Committee on Cancer/International Union against Cancer (AJCC/UICC) [25]. Individuals with a past history of allergic or autoimmune diseases were excluded from the study. The study was approved by the ethics committee of Bushehr University of medical sciences.

\section{Analysis of $\mathrm{CD}^{+} \mathrm{CD}^{+} 5^{+} \mathrm{Foxp}^{+} \mathrm{T}$ cells and $\mathrm{CD}^{+}{ }^{+} \mathrm{CD}^{\mathrm{hi}}{ }^{\mathrm{hi}} \mathrm{CD}^{\mathrm{hi}}{ }^{\mathrm{hi}} \mathrm{B}$ cells}

Peripheral blood (PB) from all patients and healthy controls was obtained, collected in EDTA-containing tube, and transferred immediately to the flowcytometry laboratory for staining and further analyses. The flowcytometric analysis was performed according to the manufacturer's instructions (BD Biosciences, USA). Peripheral blood mononuclear cells (PBMC) were stained for cell surface molecules to determine the number of cells with Treg and $\mathrm{CD} 19^{+} \mathrm{CD} 24^{\mathrm{hi}} \mathrm{CD} 38^{\mathrm{hi}}$ cells phenotype using anti-CD4PerCP-Cy5.5 and anti-CD25-FITC antibodies, anti-CD19PerCP-Cy5.5, anti-CD24-PE, and anti-CD38-FITC (BD Biosciences, USA), followed by paraformaldehyde (1\%) fixation and intracellular staining using an anti-FoxP3-PE antibody (BD Biosciences, USA) [26]. The data were analyzed with a 3-color FACSCalibur (BD Biosciences, USA), using CellQuest software (Becton-Dickinson, USA). The proportion of Treg cells was calculated as the percentage of $\mathrm{CD} 25^{+} \mathrm{FoxP}^{+}$cells within the $\mathrm{CD} 4^{+}$lymphocyte, and the proportion of $\mathrm{CD} 19^{+} \mathrm{CD} 24^{\mathrm{hi}} \mathrm{CD} 38^{\text {hi }}$ cells was calculated as the percentage of $\mathrm{CD} 24^{+} \mathrm{CD} 38^{+}$cells within the $\mathrm{CD} 19^{+}$lymphocyte gate. Two typical results of FACS scan from Treg and $\mathrm{CD} 19^{+} \mathrm{CD} 24^{\mathrm{hi}} \mathrm{CD} 38^{\text {hi }}$ cells are depicted in Fig. 1. 

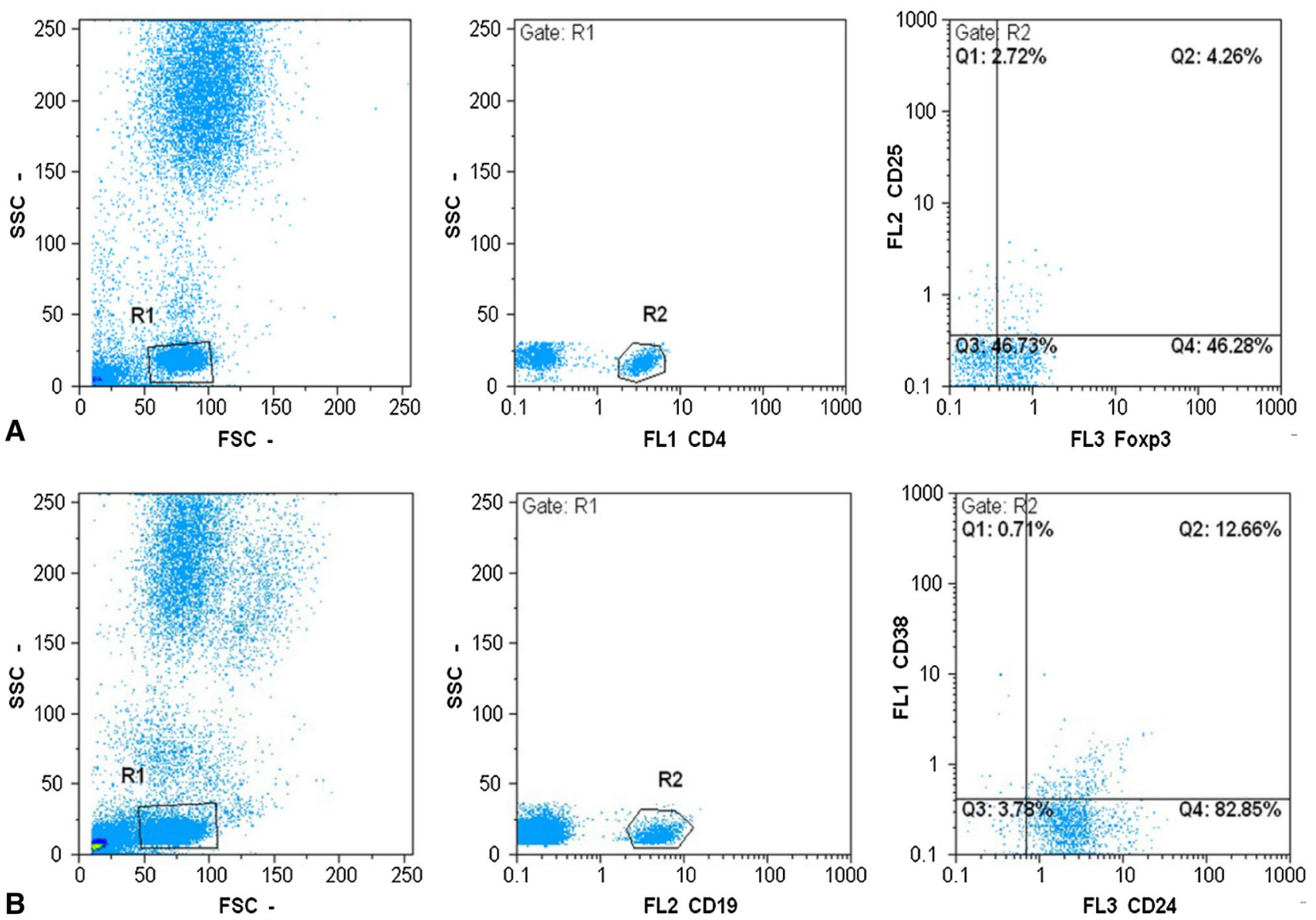

Fig. $1 \mathrm{~T}$ and B cell composition in peripheral blood. SSC (side scatter), FSC (Forward Scatter), R1, R2 (regions). a Representative gating strategy for Treg cells in the peripheral blood, Shows the

\section{Serum TGF- $\beta 1$ and IL-10 analysis}

The serum concentrations of TGF- $\beta 1$ and IL-10 were measured using an ELISA kit in accordance with the manufacturer's protocol (Boster Biological Technology Co., Wuhan, China). Samples (in duplicate) were incubated on array plates. The levels of cytokines were quantified by reference to standard curves. Determinations were performed in duplicate and the results were expressed as pg/ $\mathrm{ml}$.

\section{Statistical analysis}

T test was used to compare quantitative variables across the two groups. The significance of the $\mathrm{T}$ regulatory cell's differences between multiple groups was evaluated by Kruskal-Wallis test. Spearman correlation analysis was employed to study the relationships among CD $19{ }^{+} \mathrm{CD} 24{ }^{\text {hi }} \mathrm{CD} 38^{\text {hi }}$ cells, TGF- $\beta$, age, and Tregs. Probability values $<5 \%$ were considered statistically significant. population of $\mathrm{CD} 4{ }^{+} \mathrm{CD} 25^{+} \mathrm{FoxP} 3^{+}$cells in the test sample. b Representative gating strategy for $\mathrm{B}$ cells in the peripheral blood shows the population of $\mathrm{CD} 19^{+} \mathrm{CD} 24^{\mathrm{hi}} \mathrm{CD} 38^{\text {hi }}$ cells in the test sample

We used a generalized linear model for estimating the adjusted influence of each clinicopathological variable (reference variable) on Treg percentage (dependent variable).

\section{Results}

There were no significant age or BMI differences between patients and control groups $(P=0.18,0.98)$ (Table 1$)$.

The proportion of $\mathrm{T}$ regulatory cells, B regulatory cells, and serum concentration of TGF- $\beta 1$ were determined to be increased in Breast cancer group compared with the control group (Table 2).

Since the amount of $\mathrm{CD} 4{ }^{+} \mathrm{CD} 25^{+} \mathrm{FoxP}^{+} \mathrm{T}$ cells was shown to negatively impact breast cancer prognosis [13], we also calculated the relation of different clinicopathological variables with $\mathrm{T}$ regulatory cells. Treg percentage of patients with different clinical stages, histological grades, HER2 amplification, and lymphovascular invasion status were calculated (Fig. 2). Patients with advanced 
Table 1 Demographic and clinical characteristics of breast cancer patients

\begin{tabular}{|c|c|}
\hline Median age (range) & $45.2(30-61)$ \\
\hline Median BMI & 26.9 \\
\hline Positive breast cancer family history & $17(36.1 \%)$ \\
\hline \multicolumn{2}{|l|}{ HER2 } \\
\hline Positive & $18(38.3 \%)$ \\
\hline Negative & $29(61.7 \%)$ \\
\hline \multicolumn{2}{|l|}{ IHC status } \\
\hline $0 /+1$ & $19(40.4 \%)$ \\
\hline+2 & $16(34 \%)$ \\
\hline+3 & $12(25.5 \%)$ \\
\hline \multicolumn{2}{|l|}{ Estrogen receptor } \\
\hline Positive & $42(89.4 \%)$ \\
\hline Negative & $5(10.6 \%)$ \\
\hline \multicolumn{2}{|l|}{ Progesterone receptor } \\
\hline Positive & $39(83 \%)$ \\
\hline Negative & $8(17 \%)$ \\
\hline \multicolumn{2}{|l|}{ T stage } \\
\hline $\mathrm{T} 1$ & $17(36.2 \%)$ \\
\hline $\mathrm{T} 2$ & $23(48.9 \%)$ \\
\hline $\mathrm{T} 3$ & $7(14.9 \%)$ \\
\hline \multicolumn{2}{|l|}{$\mathrm{N}$ stage } \\
\hline No & $19(40.4 \%)$ \\
\hline N1 & $19(40.4 \%)$ \\
\hline $\mathrm{N} 2$ & $9(19.1 \%)$ \\
\hline \multicolumn{2}{|l|}{ Clinical stage } \\
\hline I & $11(23.4 \%)$ \\
\hline II & $24(51.1 \%)$ \\
\hline III & $12(25.5 \%)$ \\
\hline \multicolumn{2}{|l|}{ Histological grade } \\
\hline G1 & $12(25.5 \%)$ \\
\hline G2 & $22(46.8 \%)$ \\
\hline G3 & $13(27.7 \%)$ \\
\hline \multicolumn{2}{|l|}{ Lymphovascular invasion } \\
\hline Positive & $18(38.3 \%)$ \\
\hline Negative & $29(61.7 \%)$ \\
\hline
\end{tabular}

clinical stages and histological grades and positive HER2 amplification were more likely to have increased percentage of peripheral blood Treg cells $(P<0.05)$. Also there were no significant differences in the serum TGF- $\beta 1$ and IL-10 of patients with or without HER-2 amplification $(P=0.61,0.89)$ (see Fig. 3).
The percentage of $\mathrm{T}$ regulatory cells had a significant correlation with the percentage of $\mathrm{CD} 19^{+} \mathrm{CD} 24^{\mathrm{hi}} \mathrm{CD} 38^{\mathrm{hi}} \mathrm{B}$ cells in the peripheral blood $(\rho=0.715, P<0.001)$ and the serum levels of TGF- $\beta 1(\rho=0.815, P<0.001)$ in breast cancer patients, while no correlation was found between Tregs and age in patients $(P>0.05)$.

After calculating the relation of each variable with the percentage of Tregs one by one, a generalized linear model was used to reveal the adjusted impact of each variable on Tregs proportion (Table 3). Regarding the fact that all variables may affect each other and therefore, it may change the impact of the target variable on Tregs percentage. As you see in Table 3, advanced clinical stage, HER2 amplification, Serum TGF- $\beta$, and the percentage of peripheral blood $\mathrm{CD} 19^{+} \mathrm{CD} 24^{\mathrm{hi}} \mathrm{CD} 38^{\text {hi }}$ cells are correlated with the proportion of T regulatory cells in the peripheral blood (see Fig. 4).

\section{Discussion}

Tregs are believed to inhibit productive tumor immune surveillance and the inflammation caused by Tregs seems to promote tumorigenesis [27]. In breast cancer patients increased Tregs independently predict a worse clinical outcome. However, the mechanism and conditions through which Tregs are increased are less known [10]. CD19 ${ }^{+-}$ $\mathrm{CD} 24^{\mathrm{hi}} \mathrm{CD} 38^{\mathrm{hi}}$ cells play a key role in inflammation process and autoimmune diseases; however, the role of $\mathrm{CD} 19^{+} \mathrm{CD} 24^{\mathrm{hi}} \mathrm{CD} 38^{\text {hi }}$ cells in the development of human cancer is less studied [28]. In this study, first we focused on breast cancer and examined the percentage of $\mathrm{T}$ and $\mathrm{B}$ regulatory cells and compared them with healthy individuals. As we expected and similar to the result of other studies [12, 29], the breast cancer patients had a significantly elevated percentage of circulating $\mathrm{CD} 4{ }^{+} \mathrm{CD} 25^{+-}$ FoxP $3^{+} \mathrm{T}$ cells compared to healthy controls. We also observed this elevation in the percentage of circulating $\mathrm{CD} 19^{+} \mathrm{CD} 24^{\mathrm{hi}} \mathrm{CD} 38^{\text {hi }} \mathrm{B}$ cells compared to healthy controls. In addition to Tregs, this result could provide an important support for the role of $\mathrm{CD} 19^{+} \mathrm{CD} 24^{\mathrm{hi}} \mathrm{CD} 38^{\mathrm{hi}}$ cells in breast cancer and indicate that $\mathrm{CD} 19^{+} \mathrm{CD} 24^{\text {hi- }}$ $\mathrm{CD} 38^{\text {hi }}$ cells may also be responsible for the tolerogenic immune response in breast cancer.

HER2 amplification is regarded as a poor prognosis factor in breast cancer, which could increase the
Table 2 Tregs, $\mathrm{CD} 19^{+} \mathrm{CD} 24^{\mathrm{hi}} \mathrm{CD} 38^{\text {hi }}$ cells, TGF- $\beta 1$ and IL-10 status in study subjects

\begin{tabular}{lllr}
\hline & Breast cancer patients & Healthy controls & $P$ value \\
\hline $\mathrm{CD}^{+}{ }^{+} \mathrm{CD} 25^{+} \mathrm{FoxP}^{+}$cells & $7.29 \%$ & $4.99 \%$ & $<\mathbf{0 . 0 0 1}$ \\
$\mathrm{CD} 19^{+} \mathrm{CD} 24^{\mathrm{hi}} \mathrm{CD}^{\mathrm{hi}}{ }^{\mathrm{hi}}$ cells & $10.43 \%$ & $6.88 \%$ & $<\mathbf{0 . 0 0 1}$ \\
Serum TGF- $\beta 1$ & $150 \mathrm{pg} / \mathrm{ml}$ & $67 \mathrm{pg} / \mathrm{ml}$ & $\mathbf{0 . 0 1 7}$ \\
Serum IL-10 & $83 \mathrm{pg} / \mathrm{ml}$ & $37 \mathrm{pg} / \mathrm{ml}$ & $<\mathbf{0 . 0 0 1}$ \\
\hline
\end{tabular}

Significant $P$ values are shown in bold 

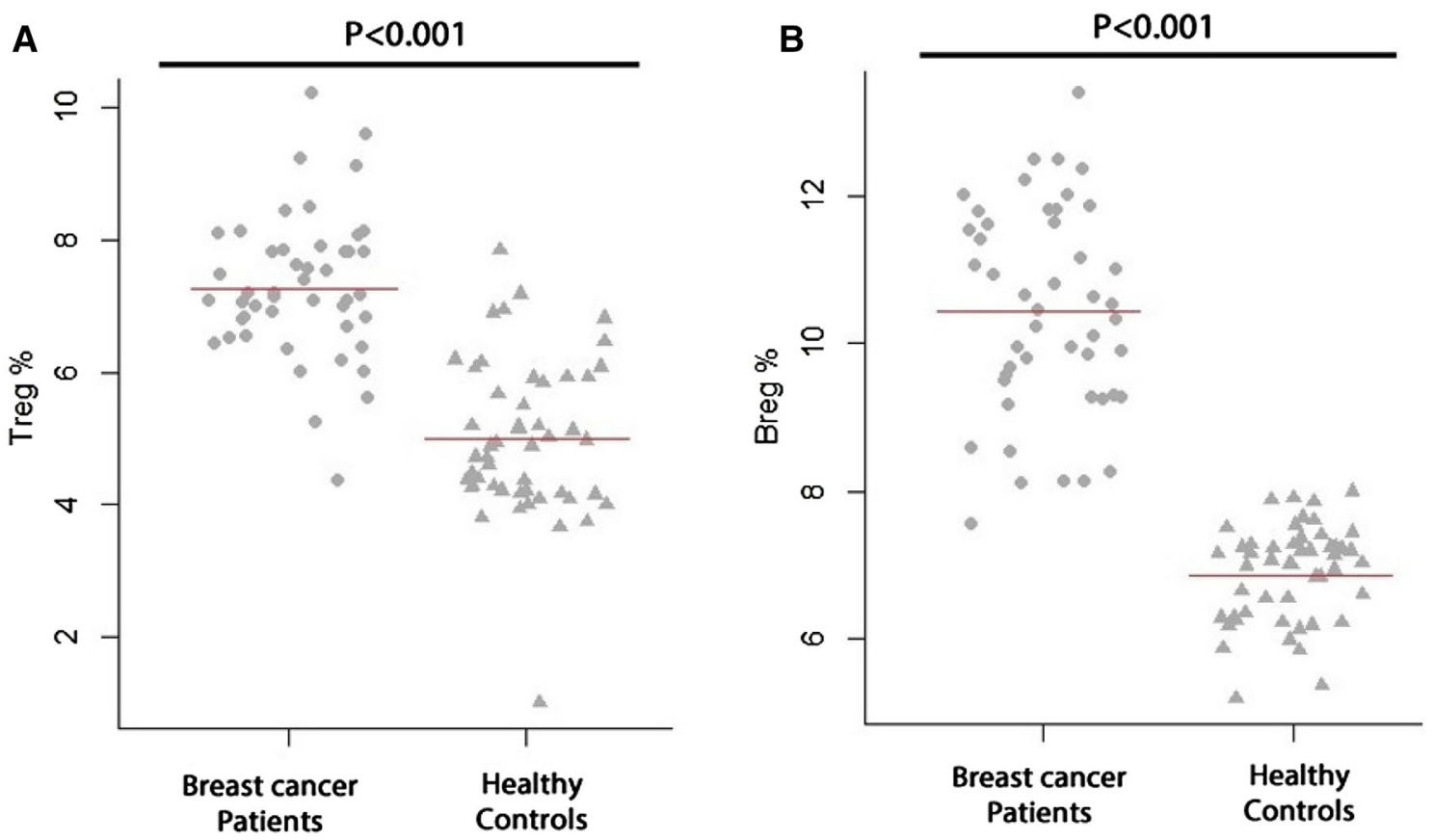

Fig. 2 The proportion of $\mathrm{CD} 4{ }^{+} \mathrm{CD} 25^{+} \mathrm{FoxP}^{+}$and $\mathrm{CD} 19^{+} \mathrm{CD} 24^{\mathrm{hi}} \mathrm{CD} 38^{\text {hi }}$ cells in Breast cancer patients and healthy controls

probability of differentiation and metastasis of tumor [30]. Previous studies have shown an increased circulating Tregs in HER2 amplified patients [12, 29]. In this study, we also observed a significant increase in circulating Tregs of HER2 amplified patients. This increased population of regulatory $\mathrm{T}$ cells in HER2 positive patients causes a suppressed immune response against tumor and could be an explanation for the poor prognosis of these patients.

We also observed an elevation of circulating Tregs in stages II and III in comparison with stage I breast cancer patients. A recent study has found that tumor-infiltrating Tregs had a higher frequency in stage III of breast cancer which suppresses the inflammation caused by $\mathrm{CD} 8^{+}$cells [31]. Since the survival rate of breast cancer patients is strongly associated with the tumor stage [3], these data also suggest a more tolerogenic immune profile in advanced stages of breast cancer.

Although crude data suggesting a higher Treg level in advanced grades, was because of the association of this variable with tumor clinical stage and HER2 amplification $[3,32]$. Another study also demonstrated that there is no association between circulating Tregs and tumor grade [12]. Since there was a low population of patients with negative hormone receptor and it was not statistically valuable, we did not include hormone receptors in our model analysis.
A variety of mechanisms have been proposed by which Treg cells mediate inhibition of both $\mathrm{CD}^{+}$and $\mathrm{CD} 8^{+}$ effector $T$ cells, including cytokines such as TGF- $\beta$ and IL-10 [33]. Bregs are also capable of directly inducing anergy of Th1 cells, CD8, and CD4 T cells [34] or indirectly by converting Tregs $[19,22]$. Some studies indicated that the Tregs immunosuppressive role in tumors is mediated by Bregs [35]. In this study we observed that increased $\mathrm{CD} 19^{+} \mathrm{CD} 24^{\mathrm{hi}} \mathrm{CD} 38^{\text {hi }}$ B cells positively correlate with levels of circulating Tregs. This result could support the hypothesis that $\mathrm{CD} 19^{+} \mathrm{CD} 24^{\text {hi- }}$ $\mathrm{CD} 38^{\text {hi }}$ cells are inducing their immunosuppressive effects through increasing circulating Tregs in breast cancer. A recent study showed a positive correlation between $\mathrm{CD} 19^{+} \mathrm{CD} 24^{\mathrm{hi}} \mathrm{CD} 38^{\mathrm{hi}}$ cells and tumor-infiltrating $\mathrm{CD} 4{ }^{+} \mathrm{FoxP}^{+} \mathrm{T}$ cells in a TGF- $\beta$ dependent way in gastric cancer patients and concluded that $\mathrm{CD} 19^{+-}$ $\mathrm{CD} 24^{\mathrm{hi}} \mathrm{CD} 38^{\mathrm{hi}}$ cells involve in gastric cancer immune scape [22]. In our study a significant correlation was found between serum TGF- $\beta$ and Tregs which suggests that the increase in circulating Tregs may be TGF- $\beta$ dependent in breast cancer patients. Previous studies mentioned the role of TGF- $\beta$ in developing Tregs through expression of Foxp3 in $\mathrm{CD}^{+}$cells [36] and this correlation confirms these results.

Some limitations were observed in this study, like the complex procedures of flowcytometry and also the fact that 


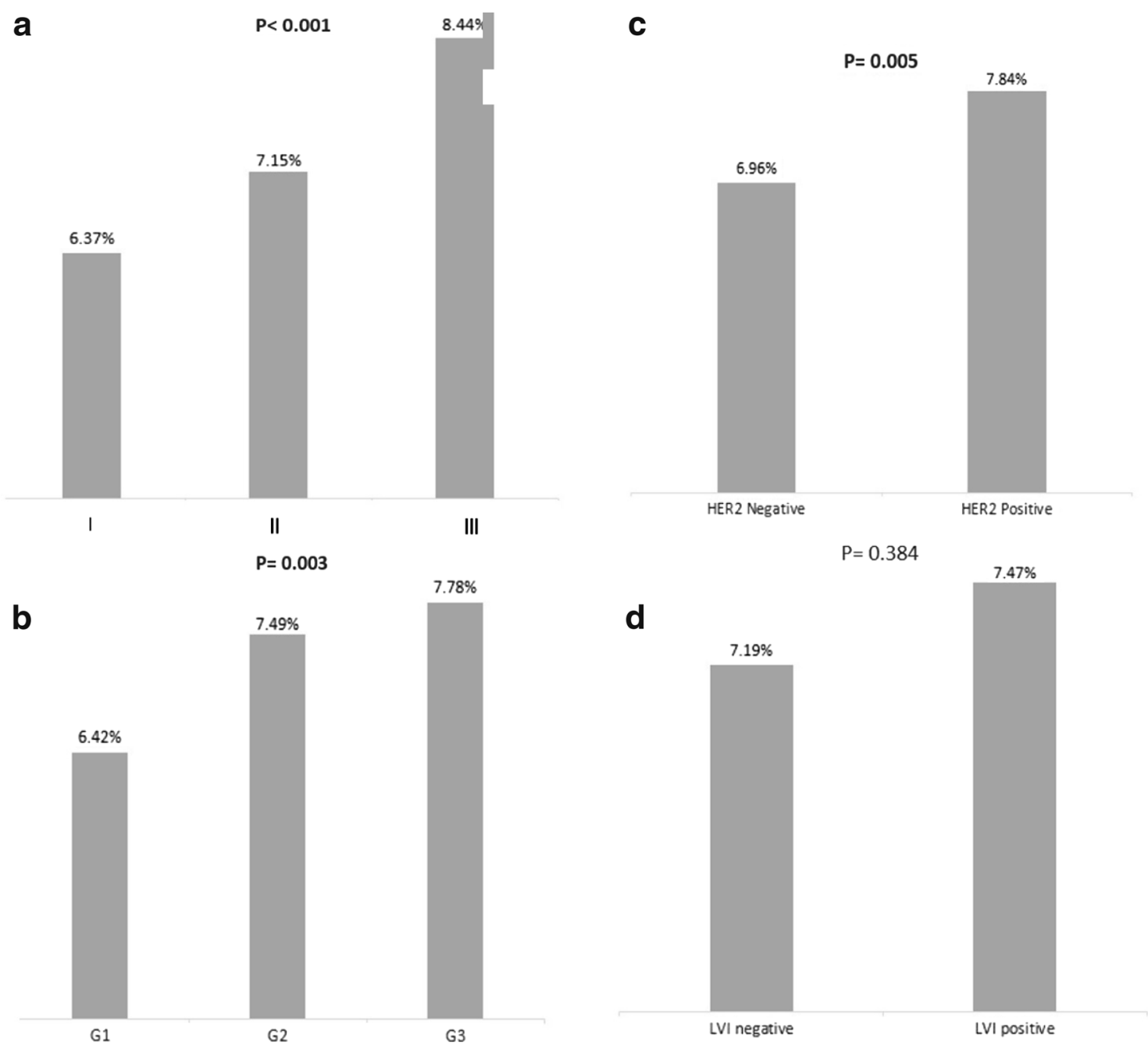

Fig. 3 The percentage of T regulatory cells of breast cancer patients with different; a clinical stages, b histological grades, $\mathbf{c}$ HER2 amplification status, d lymphovascular invasion status

Table 3 Generalized linear model for Tregs and the impact of clinicopathological variables

\begin{tabular}{llr}
\hline & Adjusted impact $(95 \%$ CI $)$ & $P$ value \\
\hline Clinical stage (I, II) & $0.44(0.00-0.88)$ & 0.051 \\
Clinical stage (I, III) & $1.15(0.50-1.80)$ & $<\mathbf{0 . 0 0 1}$ \\
Histological grade (G1, G2) & $0.28(-0.16$ to 0.74$)$ & 0.216 \\
Histological grade (G1, G3) & $0.30(-0.24$ to 0.85$)$ & 0.281 \\
HER2 status (HER2-, HER2+) & $0.58(0.21-0.96)$ & $\mathbf{0 . 0 0 2}$ \\
LVI status $(-,+)$ & $0.06(-0.27$ to 0.40$)$ & 0.717 \\
CD19 ${ }^{+}$CD24 ${ }^{\text {hi }}$ CD38 ${ }^{\text {hi }}$ cells & $0.21(0.04-0.37)$ & $\mathbf{0 . 0 1 2}$ \\
TGF- $\beta$ & $0.00(0.00-0.00)$ & $\mathbf{0 . 0 1 9}$ \\
IL-10 & $0.00(0.00-0.00)$ & 0.705 \\
Age & $0.00(-0.02$ to 0.02$)$ & 0.773 \\
\hline
\end{tabular}

Significant $P$ values are shown in bold we intended to gather blood samples before any treatment was conducted.

In conclusion, our results show that $\mathrm{CD} 19^{+} \mathrm{CD} 24^{\mathrm{hi}-}$ $\mathrm{CD} 38^{\text {hi }}$ cells might be involved in the systemic suppression of breast cancer's immune response, whether directly or through increasing the proportion of circulating Tregs. Also advanced TNM stage and HER2 amplification are other conditions in which breast cancer patients have a high 

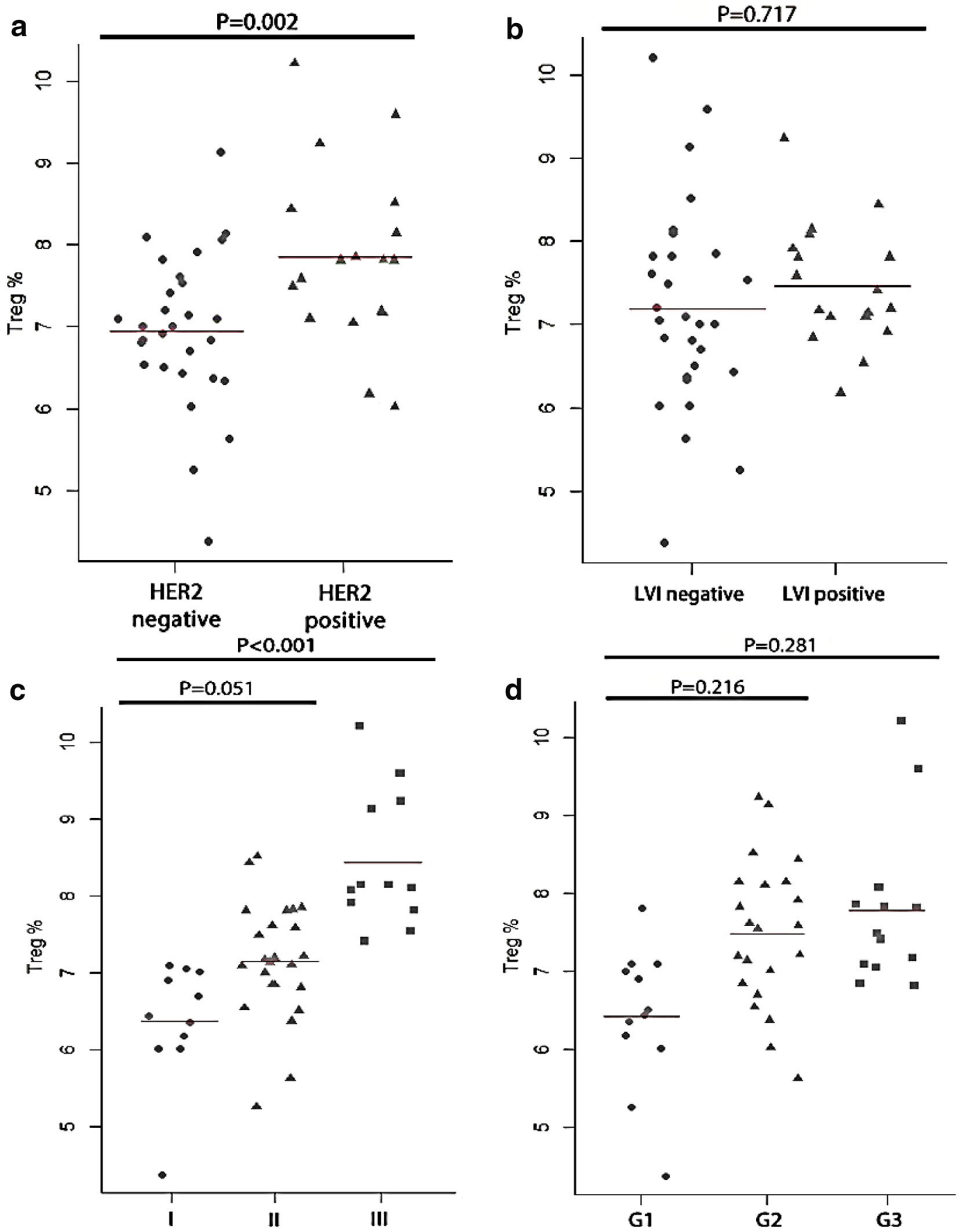

Fig. 4 The percentage of T regulatory cells in patients with different. a HER2 amplification. b LVI status. $\mathbf{c}$ clinical stages, $\mathbf{d}$ histological grades. $P$ values are calculated based on the generalized linear model

proportion of circulating Tregs. Of course, more studies should explore the underlying mechanisms that increase the circulating and tumor infiltrating Tregs and investigate the possible role of Tregs in a worse clinical outcome in breast cancer.
Acknowledgements Special thanks to Dr. Yasaman Khosravi and Mr. Pouya Iranpour for their helpful assistance.

\section{Compliance with ethical standards}

Conflict of interest The authors declare that they have no conflict of interest. 


\section{References}

1. Zob D, Vasilescu M, Gruia M, Anghel R. Breast cancer. Screening criteria. Chirurgia (Bucur). 2013;108(4):557-62.

2. Watanabe MA, Oda JM, Amarante MK, Cesar Voltarelli J. Regulatory $\mathrm{T}$ cells and breast cancer: implications for immunopathogenesis. Cancer Metastasis Rev. 2010;29(4):569-79. doi:10.1007/s10555-010-9247-y.

3. Rakha EA, Martin S, Lee AH, Morgan D, Pharoah PD, Hodi Z, Macmillan D, Ellis IO. The prognostic significance of lymphovascular invasion in invasive breast carcinoma. Cancer. 2012;118(15):3670-80. doi:10.1002/cncr.26711.

4. Wolff AC, Hammond ME, Hicks DG, Dowsett M, McShane LM, Allison KH, Allred DC, Bartlett JM, Bilous M, Fitzgibbons P, Hanna W, Jenkins RB, Mangu PB, Paik S, Perez EA, Press MF, Spears PA, Vance GH, Viale G, Hayes DF. Recommendations for human epidermal growth factor receptor 2 testing in breast cancer: American Society of Clinical Oncology/College of American Pathologists clinical practice guideline update. J Clin Oncol. 2013;31(31):3997-4013. doi:10.1200/JCO.2013. 50.9984.

5. Grivennikov SI, Greten FR, Karin M. Immunity, inflammation, and cancer. Cell. 2010;140(6):883-99. doi:10.1016/j.cell.2010.01.025.

6. Wing K, Sakaguchi S. Regulatory T cells exert checks and balances on self tolerance and autoimmunity. Nat Immunol. 2010;11(1):7-13. doi:10.1038/ni.1818.

7. Rech AJ, Mick R, Kaplan DE, Chang KM, Domchek SM, Vonderheide RH. Homeostasis of peripheral FoxP3(+) CD4 (+) regulatory $\mathrm{T}$ cells in patients with early and late stage breast cancer. Cancer Immunol Immunother. 2010;59(4):599-607. doi:10.1007/s00262-009-0780-x.

8. Campbell DJ, Koch MA. Phenotypical and functional specialization of FOXP3 + regulatory $\mathrm{T}$ cells. Nat Rev Immunol. 2011;11(2):119-30. doi:10.1038/nri2916.

9. Wilke CM, Wu K, Zhao E, Wang G, Zou W. Prognostic significance of regulatory $\mathrm{T}$ cells in tumor. Int $\mathrm{J}$ Cancer. 2010;127(4):748-58. doi:10.1002/ijc.25464.

10. Li YQ, Liu FF, Zhang XM, Guo XJ, Ren MJ, Fu L. Tumor secretion of CCL22 activates intratumoral Treg infiltration and is independent prognostic predictor of breast cancer. PLoS One. 2013;8(10):e76379. doi:10.1371/journal.pone.0076379.

11. Yuan XL, Chen L, Li MX, Dong P, Xue J, Wang J, Zhang TT, Wang XA, Zhang FM, Ge HL, Shen LS, Xu D. Elevated expression of Foxp3 in tumor-infiltrating Treg cells suppresses T-cell proliferation and contributes to gastric cancer progression in a COX-2-dependent manner. Clin Immunol. 2010;134(3): 277-88. doi:10.1016/j.clim.2009.10.005.

12. Decker T, Fischer G, Bucke W, Bucke P, Stotz F, Gruneberger A, Gropp-Meier M, Wiedemann G, Pfeiffer C, Peschel C, Gotze K. Increased number of regulatory $\mathrm{T}$ cells (T-regs) in the peripheral blood of patients with Her-2/neu-positive early breast cancer. J Cancer Res Clin Oncol. 2012;138(11):1945-50. doi:10.1007/ s00432-012-1258-3.

13. Watanabe MA, Oda JM, Amarante MK, Cesar Voltarelli J. Regulatory $\mathrm{T}$ cells and breast cancer: implications for immunopathogenesis. Cancer Metastasis Rev. 2010;29(4):569-79. doi:10.1007/ s10555-010-9247-y.

14. Ouyang W, Beckett O, Ma Q, Li MO. Transforming growth factor-beta signaling curbs thymic negative selection promoting regulatory $\mathrm{T}$ cell development. Immunity. 2010;32(5):642-53. doi:10.1016/j.immuni.2010.04.012.

15. Gupta S, Joshi K, Wig JD, Arora SK. Intratumoral FOXP3 expression in infiltrating breast carcinoma: its association with clinicopathologic parameters and angiogenesis. Acta Oncol. 2007;46(6):792-7. doi:10.1080/02841860701233443.
16. Fremd C, Schuetz F, Sohn C, Beckhove P, Domschke C. B cellregulated immune responses in tumor models and cancer patients. Oncoimmunology. 2013;2(7):e25443. doi:10.4161/onci.25443.

17. Wolf SD, Dittel BN, Hardardottir F, Janeway CA Jr. Experimental autoimmune encephalomyelitis induction in genetically B cell-deficient mice. J Exp Med. 1996;184(6):2271-8.

18. Blair PA, Norena LY, Flores-Borja F, Rawlings DJ, Isenberg DA, Ehrenstein MR, Mauri C. CD19(+)CD24(hi)CD38(hi) B cells exhibit regulatory capacity in healthy individuals but are functionally impaired in systemic Lupus Erythematosus patients. Immunity. 2010;32(1):129-40. doi:10.1016/j.immuni.2009.11.009.

19. Lemoine S, Morva A, Youinou P, Jamin C. Human T cells induce their own regulation through activation of B cells. J Autoimmun. 2011;36(3-4):228-38. doi:10.1016/j.jaut.2011.01.005.

20. Horikawa M, Minard-Colin V, Matsushita T, Tedder TF. Regulatory B cell production of IL-10 inhibits lymphoma depletion during CD20 immunotherapy in mice. $\mathbf{J}$ Clin Invest. 2011;121(11):4268-80. doi:10.1172/JCI59266.

21. Schioppa T, Moore R, Thompson RG, Rosser EC, Kulbe H, Nedospasov S, Mauri C, Coussens LM, Balkwill FR. B regulatory cells and the tumor-promoting actions of TNF-alpha during squamous carcinogenesis. Proc Natl Acad Sci USA. 2011;108(26):10662-7. doi:10.1073/pnas.1100994108.

22. Wang WW, Yuan X, Chen H, Xie G, Ma Y, Zheng Y, Zhou Y, Shen L. CD19 + CD24hiCD38hiBregs involved in downregulate helper $\mathrm{T}$ cells and upregulate regulatory $\mathrm{T}$ cells in gastric cancer. Oncotarget. 2015;6(32):33486-99.

23. Elston CW, Ellis IO. Pathological prognostic factors in breast cancer. I. The value of histological grade in breast cancer: experience from a large study with long-term follow-up. Histopathology. 1991;19(5):403-10.

24. Rakha EA, Reis-Filho JS, Baehner F, Dabbs DJ, Decker T, Eusebi V, Fox SB, Ichihara S, Jacquemier J, Lakhani SR, Palacios J, Richardson AL, Schnitt SJ, Schmitt FC, Tan PH, Tse GM, Badve S, Ellis IO. Breast cancer prognostic classification in the molecular era: the role of histological grade. Breast Cancer Res. 2010;12(4):207. doi:10.1186/bcr2607.

25. Murthy V, Chamberlain RS. Further expansion of the AJCC/ UICC breast cancer staging system to encompass unique problems in the developing world. Ann Surg Oncol. 2011;18(Suppl 3):S278-80. doi:10.1245/s10434-011-1649-8.

26. Miyoshi H, Uchida K, Taniguchi T, Yazumi S, Matsushita M, Takaoka M, et al. Circulating naive and CD4 + CD25high regulatory $\mathrm{T}$ cells in patients with autoimmune pancreatitis. Pancreas. 2008;36(2):133-40.

27. Disis ML. Immune regulation of cancer. $J$ Clin Oncol 2010;28(29):4531-8. doi:10.1200/JCO.2009.27.2146.

28. Khoder A, Sarvaria A, Alsuliman A, Chew C, Sekine T, Cooper N, Mielke S, de Lavallade H, Muftuoglu M, Fernandez Curbelo I, Liu E, Muraro PA, Alousi A, Stringaris K, Parmar S, Shah N, Shaim H, Yvon E, Molldrem J, Rouce R, Champlin R, McNiece I, Mauri C, Shpall EJ, Rezvani K. Regulatory B cells are enriched within the IgM memory and transitional subsets in healthy donors but are deficient in chronic GVHD. Blood. 2014;124(13): 2034-45. doi:10.1182/blood-2014-04-571125.

29. Perez SA, Karamouzis MV, Skarlos DV, Ardavanis A, Sotiriadou NN, Iliopoulou EG, Salagianni ML, Orphanos G, Baxevanis CN, Rigatos G, Papamichail M. CD4 + CD25 + regulatory T-cell frequency in HER-2/neu (HER)-positive and HER-negative advanced-stage breast cancer patients. Clin Cancer Res. 2007;13(9):2714-21. doi:10.1158/1078-0432.CCR-06-2347.

30. Gheybi MK, Baradaran A, Mohajeri MR, Ostovar A, Hajalikhani P, Farrokhi S. Validity of immunohistochemistry method in predicting HER-2 gene status and association of clinicopathological variables with it in invasive breast cancer patients. APMIS. 2016;124(5):365-71. 
31. Zhu S, Lin J, Qiao G, Xu Y, Zou H. Differential regulation and function of tumor-infiltrating $\mathrm{T}$ cells in different stages of breast cancer patients. Tumour Biol. 2015;36(10):7907-13. doi:10. 1007/s13277-015-3507-y.

32. Rakha EA, El-Sayed ME, Lee AH, Elston CW, Grainge MJ, Hodi Z, Blamey RW, Ellis IO. Prognostic significance of Nottingham histologic grade in invasive breast carcinoma. J Clin Oncol. 2008;26(19):3153-8. doi:10.1200/JCO.2007.15.5986.

33. Shevach EM, Davidson TS, Huter EN, Dipaolo RA, Andersson J. Role of TGF-Beta in the induction of Foxp3 expression and T regulatory cell function. J Clin Immunol. 2008;28(6):640-6. doi:10.1007/s10875-008-9240-1.
34. Balkwill F, Montfort A, Capasso M. B regulatory cells in cancer. Trends Immunol. 2013;34(4):169-73. doi:10.1016/j.it.2012.10. 007.

35. Zhang Y, Eliav Y, Shin SU, Schreiber TH, Podack ER, Tadmor $\mathrm{T}$, Rosenblatt JD. B lymphocyte inhibition of anti-tumor response depends on expansion of Treg but is independent of B-cell IL-10 secretion. Cancer Immunol Immunother. 2013;62(1):87-99. doi:10.1007/s00262-012-1313-6.

36. Schwartz M, Zhang Y, Rosenblatt JD. B cell regulation of the anti-tumor response and role in carcinogenesis. J Immunother Cancer. 2016;4:40. 